ance. The introduction of carbides in the necessary concentration in the equivalent sintered alloy presents difficulties, due to reaction between the carbon and the oxide present in the metal powders used. The possible solution here may be the use of alternative precipitates to carbides for the development of satisfactory high-temperature strength.

Metal - ceramic mixtures are a comparatively new field for research and development of materials for high-temperature service. Metal-bonded alumina compounds figure quite prominently in the investigations which have so far been carried out. Satisfactory bonding between the metal and ceramic is essential for strength at high temperatures, and basic studies of the wetting of ceramics with metals form an important part of research work in this field. As in the case of titanium carbides, the work has shown that a thin layer of bond metal has much greater strength than that of the bond metal in massive form, and this is attributed to the inability of the thin layer of metal to deform plastically. Increasing information is becoming available on the high-temperature properties of ceramies bonded with metals. The optimum composition would appear to be in the neighbourhood of about 50 per cent by weight of the metal. The interesting point of view has been expressed that for optimum properties and, in particular, good resistance to thermal shock, the metal network and the ceramic network should both be continuous. I. JENKINs

\section{EDUCATION AND TRAINING OF RADIO ENGINEERS}

$\mathrm{T}$ HE present demand of industry and the Services for more radio engineers has emphasized the continuing difficulties of education and training in this field. Following a series of reports made by the British Institution of Radio Engineers on this subject, a recent meeting of the Institution in London was devoted to examining some of the present problems.

Opening the discussion, Prof. E. E. Zepler (professor of electronics in the University of Southampton) stated that there is now scarcely an industry which does not, in one way or another, use either electrical communications or what is now called industrial electronics. The British Institution of Radio Engineers has recently decided to extend the syllabus of its graduateship examination by including industrial electronics as a specialized subject as from 1956 .

The universities have not, so far, final degree courses in radio engineering. Many universities provide specialized papers in communications and radio physics; but all too fow universities have, in fact, a chair of radio or electronic engineering. In consequence, education and training in the universities are not $a_{0}$ main contribution towards the solution of our man-power shortage and, in the main, recruitment in the industry comes through the technical college.

Prof. Zepler feels that universities which, for various reasons, will not cater for a degree in electronics might be prepared to provide a fourth-year course, devoted wholly to electronics, for those who have taken a degree in physics or in electrical engineering.

Prof. Zepler invited discussion on the question of whether industry co-operates sufficiently with the universities and technical colleges in providing sandwich schemes and part-time release.

He said that the experience of some of the examining bodies, including the British Institution of Radio Engineers and the City and Guilds of London Institute, was that examination results show that students are, in the main, inadequately prepared for these examinations, but suggested that the results are not wholly the fault of the technical colleges; it might well be that basic training at the grammar schools and secondary modern schools is not adequate.

Prof. E. Williams (professor of electrical engineering in University College, Cardiff) said that he has no doubt that, at one stage of the country's educational development, classics provided the quickest and most readily available training in straight thinking. But nowadays we must surely quarrel with the principle that "it doesn't matter what you teach so long as it trains a man to think". "The practice of radio and electronic engineering now rests on so extensive a basis of specialized physical principle and of particularized application of mathematics that its study is as much a contribution to true education as is the study of any pure science. The desirable limits of specialization are imposed, not by educational considerations, but by vocational requirements. A very broad study of physical principle is undoubtedly needed, but Prof. Williams holds that, in the limited time available, it is both unprantical and unnecessary to prescribe a similarly broad study of related technologies. Professional insritutions have not the same function as universities, and it is reasonable to expect greater specialization in courses leading to the examinations of the former. Prof. Williams thinks that the development of education and training in radio and electronic engineering will be seriously retarded unless the policy of regarding 'electrical engineering' as a convenient indivisible unit of subject-matter is abandoned.

Mr. Hugh Warren (principal of the South East London Technical College) represented the Association of Principals of Technical Institutes at the discussion. He feels that the term 'radio' should not be restricted to the connotation with which it might have started many years ago. Instrumentation, control, radio-frequency heating, radar and an everwidening field of applications now have to be added to the fields of valve manufacture, telecommunications and recording and amplifying equipment.

Mr. Warren said that perhaps half the 250 or so technical colleges in Britain have seriously concerned themselves with the training of radio engineers. Just as there is no British standard radio engineer, so there is no attempt to prescribe a single course. There are many courses and they reflect the complexity and variety of this rapidly expanding industry. They prepare for a wide variety of qualificationsdegrees, diplomas, the National and Higher National Certificates, a number of different City and Guilds Certificates, and the examinations of the professional institutions. These fairly well-defined levels of qualifications blend into each other. Mr. Warren defied anyone to delimit the exact boundaries of a professional engineer. He paid a tribute to the real co-operation both of organized industry and of individuals in industry, in the matter of courses and equipment. After comparing British and French systems of apprentice-training, Mr. Warren asked for guidance on the question of whether a new certificate in radio is needed. In mechanical engineering there is a certificate for those who are not going to be 
designers, but are going to be very good technicians, if not technologists. There is nothing quite comparable in radio. Mr. Warren wondered whether the technical college should, as in France, undertake more of the practical side of apprentice-training-or whether industry is content to undertake this. $\mathrm{He}$ concluded with a plea that education should find room for social thinking and an awareness of the economic and philosophical problems of our age.

Mr. R. E. Burnett (manager of the Education and Technical Personnel Department of Marconi's Wireless Telegraph Co.), expressing personal views, maintained that the radio industry is playing a full part in co-operation with the universities and technical colleges in stimulating recruitment and in planning the future training and education of radio engineers.

Agreeing that there is still a tremendous shortage of professional engineers in this field, Mr. Burnett stated that the larger companies are spending more and more money in developing their own training schemes, including the provision of the equivalent of college facilities. The smaller, but progressive, firms are in many cases making a proportional contribution to the problem of providing adequate training by co-operating with local technical colleges and in some cases making arrangements with the larger companies who are able to provide their own schemes. He advocated that there might be an extension of this principle in view of the increasing number of organizations which are not at present in a position to set up their own individual training schemes.

Agreeing with Mr. Warren that the question of selection is important, Mr. Burnett feels that too little is done to help the student who fails to reach professional status or even Higher National Certificate level. He advocated that courses and examinations should be so organized as to enable the candidate who cannot reach the higher level to be accommodated in the technician or craft level. Similarly, not enough is done to encourage the successful craft apprentice to go forward to secure professional status.

Some graduates hold the view that, having completed their university training, it is not necessary to follow on with a form of training or apprenticeship course. Most of the larger companies, however, have found that it is to the ultimate advantage of the graduate to undertake further training in the shape of an apprenticeship course, if only to have a firsthand understanding of the working of the various departments which go to make up a large organiza. tion. The graduate who leaves the university and is straightway employed on a special task tends to become insular in his outlook and not to use fully his academic training.

In general, the output of the universities is so comparatively small that industry is compelled to look to the technical colleges and the other examining institutions for recruitment to its professional ranks. In return, industry must be conscious of the need for arranging sandwich and similar courses (at present in very small numbers) in order to provide adequate training facilities for able young men who, for one reason or another, cannot undertake a full-time university course.

Other speakers in the discussion dealt with the shortage of teachers. Too many technical colleges are dependent on the services of the part-time lecturer who, by reason of his main job in industry, is unable to give adequate time and thought to teaching.

Mr. E. M. Wareham (chief engineer of Sanders Electronics, Ltd.) feels that there is a serious gap between the standard of training of a university graduate in electrical engineering or physics, and the standard required in the design and development laboratories. The average student has to have at least two years training and general experience before being entrusted with responsible electronic work in the design and development field.

Mr. C. W. Robson (head of the Electrical Engineering Department of the South East London Technical College) feels that very few firms are prepared to enter into an apprenticeship scheme which will give the technical colleges the maximum opportunity of playing their part in the thorough training of the younger man.

The technical colleges are, in the main, dependent on recruitment at the age of sixteen or seventeen years, when the work of the technical college has to be integrated with the activity of the employing firm. In the Ordinary National Certificate, Mr. Robson feels that there should be greater specialization in radio and electronics.

Other speakers expressed the view that industry, and particularly the radio industry, does not do sufficient to publicize in the schools the opportunities available in industry. The first contribution made by the radio industry in this connexion is the excellent booklet distributed by the Ministry of Labour on radio and electronics as a career.

It was suggested that a difficulty in persuading youth to go in for a radio engineering career is the fact that, in the first two or three years of technical college training, students are confined to training in electrical engineering. Mr. W. Dunn expressed the belief that, if the radio apprentice could, in his first three-year technical college course, secure acknowledgment and reward in the shape of an Ordinary National Certificate in Radio Engineering, his interest would be much better maintained than under the present arrangement of expecting him to take an ordinary National Certificate in electrical engineering before starting any serious study of radio and electronics.

E. Williams

\section{OBITUARIES}

\section{Sir Shanti Bhatnagar, O.B.E., F.R.S.}

ON New Year's Day, India lost a great public servant, Sir Shanti Swarup Bhatnagar, a man of exceptional ability and immense energy. As director of the Council of Scientific and Industrial Research, secretary of the Ministry of Scientific Research, and chairman of the University Grants Committee, he was the Prime Minister's right-hand man in implementing the policy to put science in the forefront of India's plan for the future. When inaugurating the forty-second session of the Indian Science Congress at Baroda on January 4, Mr. Nehru paid him tribute: "I have co-operated for the last six or seven years or more with Dr. Bhatnagar who, I think, has doneI say this with all respect due to others-more than anyone else for scientific development in India".

Twelve new national institutes and laboratories have been built, equipped and established in various 